\title{
BMJ Global Health Decolonising human rights: how intellectual property laws result in unequal access to the COVID-19 vaccine
}

\author{
Sharifah Sekalala (D) , ${ }^{1}$ Lisa Forman (D) ,2 Timothy Hodgson, ${ }^{3}$ Moses Mulumba, ${ }^{4}$ \\ Hadijah Namyalo-Ganafa, ${ }^{5}$ Benjamin Mason Meier ${ }^{6}$
}

\begin{abstract}
To cite: Sekalala S, Forman L, Hodgson T, et al. Decolonising human rights: how intellectual property laws result in unequal access to the COVID-19 vaccine. BMJ Global Health 2021;6:e006169. doi:10.1136/ bmjgh-2021-006169
\end{abstract}

Handling editor Seye Abimbola

Received 30 April 2021

Accepted 11 June 2021

D) Check for updates

(c) Author(s) (or their employer(s)) 2021. Re-use permitted under CC BY-NC. No commercial re-use. See rights and permissions. Published by BMJ.

${ }^{1}$ Warwick Law School, University of Warwick, Coventry, UK ${ }^{2}$ Dalla Lana School of Public Health, University of Toronto Toronto, Ontario, Canada ${ }^{3}$ International Commission of Jurists, Johannesburg, South Africa

${ }^{4}$ Center for Health, Human Rights and Development, Kampala, Uganda

${ }^{5}$ School of Law, Makerere University, Kampala, Uganda ${ }^{6}$ Department of Public Policy, University of North Carolina at Chapel Hill, Chapel Hill, North Carolina, USA

\section{Correspondence to} Dr Sharifah Sekalala; sharifah.sekalala@warwick. ac.uk

\section{ABSTRACT}

The recent rapid development of COVID-19 vaccines offers hope in addressing the worst pandemic in a hundred years. However, many countries in the Global South face great difficulties in accessing vaccines, partly because of restrictive intellectual property law. These laws exacerbate both global and domestic inequalities and prevent countries from fully realising the right to health for all their people. Commodification of essential medicines, such as vaccines, pushes poorer countries into extreme debt and reproduces national inequalities that discriminate against marginalised groups. This article explains how a decolonial framing of human rights and public health could contribute to addressing this systemic injustice. We envisage a human rights and global health law framework based on solidarity and international cooperation that focuses funding on long-term goals and frees access to medicines from the restrictions of intellectual property law. This would increase domestic vaccine production, acquisition and distribution capabilities in the Global South.

\section{INTRODUCTION}

The COVID-19 pandemic is one of the biggest health crises that the world has faced in the last century. While many COVID-19 vaccines have been rapidly developed, offering hope to billions, many countries face a herculean task in accessing them, in part because of restrictive intellectual property (IP) laws. This is because vaccine patents, which are a form of IP rights, lead to production monopolies that contribute to increased prices and decreased access. This injustice has been described as 'vaccine apartheid' because it creates stark disparities in vaccine access between countries in the Global North and those in the Global South, as well as between elites and others within countries.

In this article, we show that the existing application of IP law exacerbates already severe global and domestic inequalities and prevents many countries in the Global South from progressively realising the right to health for all of their people. This, in turn,
Summary box

Restrictive intellectual property laws inhibit access to essential medicines such as vaccines.

- Commodification of essential medicines such vaccines can push countries into greater indebtedness and increase national and international inequalities.

- A decolonised approach to human rights in global health can enable us to address this systemic injustice.

- A decolonised approach demands three things Firstly, reparative justice, not through charitable models such as COVAX but through redistribution, secondly increasing manufacturing capacity of states from the global south and thirdly that states should pay greater attention to the human rights responsibilities of corporations.

amounts to a violation of states' human rights obligations to respect, protect and fulfil the right to health. We suggest that the best way to address these structural global inequities is through a decolonised approach to human rights in global health. Decolonisation refers to the undoing of colonial rule over subordinate countries but has taken on a wider meaning as the 'freeing of minds from colonial ideology', in particular by addressing the ingrained idea that to be colonised was to be inferior. Decolonisation enables us to critique positions of power and dominant culture. ${ }^{1}$ In global health, decolonisation is a political tradition rooted in Global South struggles against colonisation, exploitative 'development' agendas, apartheid and access to public health, including inequity in access to essential medicines. ${ }^{2}$ Calls to decolonise global health are not new, and indeed they have gained urgency due to the power asymmetries illustrated by the COVID-19 crisis. ${ }^{34}$ In this paper, a 'decolonial' framing of human rights in global health enables us to focus on ways in which structural or systemic issues reproduce inequalities and, we hope, can 
help to galvanise more effective human rights struggles from below. ${ }^{5-8}$ In order to do so, we call for reparative redistributing of resources in global solidarity, shifting vaccine access from a charitable plea to a legal obligation, increasing manufacturing capacity in the Global South and clarifying human rights responsibilities of pharmaceutical corporations themselves.

International and domestic responses to COVID-19, including in respect of vaccine access, have been highly politicised. ${ }^{9}$ Thus, a decolonised approach allows us to consider ways in which the entire patent regime-and existing interpretations of international human rights law that defer to its applications-commodifies essential medicines, undermining universal health coverage. In this article, we illustrate how, beyond making essential medicines unaffordable for countries in the Global South, the commodification of vaccines is pushing countries into greater indebtedness and reproducing national inequalities through dual-track systems that discriminate against poorer and marginalised groups, thereby making it harder for these countries to achieve the realisation of the right to health for all.

The commodification of essential medicines is the consequence of the prevalent system of global capitalism that allows manufacturers and states to value financial profit over human life. In this paper, we define neocolonialism to mean that although many global South States are outwardly independent and sovereign in many respects, they remain beholden both to states in the Global North and increasingly to multinational corporations. ${ }^{9}$ This relationship is exemplified in the case of IP rights protections, which low and middle-income countries (LMIC) are pressured into adopting and respecting in order to enter into bilateral or regional free trade or investment agreements with high-income countries and/ or receive investments and loans from global financial institutions. ${ }^{10}$

In this paper, we first outline what a human rights approach to realising access to COVID-19 vaccines entails when a decolonising lens is not used. We illustrate the limitations of this approach in our discussion of the competing IP framework which governs IP rights and stymies the human rights frameworks for access to essential medicines such as vaccines. We reveal the resulting inequalities both between countries and within countries. Finally, we outline how a decolonised approach could improve access to vaccines both, for this crisis and also for future crises.

\section{A HUMAN RIGHTS APPROACH TO REALISING ACCESS TO COVID-19 VACCINES}

International human rights law provides a universal framework for advancing global health with justice, transforming moral imperatives into legal entitlements. The right to the highest attainable standard of health, first articulated in 1946 in the WHO Constitution, has evolved through the progression of treaties such as the
International Covenant on Economic, Social and Cultural Rights (ICESCR).${ }^{11}$ Nearly every country in the world has now ratified at least one international agreement that imposes specific obligations that lead to the realisation of the right to health, including explicit obligations to prevent, treat and control epidemics. ${ }^{12}$

In the specific context of COVID-19 vaccines, the United Nations (UN) Committee on Economic, Social and Cultural Rights (CESCR), responsible for interpreting the ICESCR, has emphasised that states 'have a duty to prevent intellectual property and patent legal regimes from undermining the enjoyment of economic, social and cultural rights', and that the IP regime should be interpreted and implemented in a manner supportive of the duty of states 'to protect public health'. ${ }^{13}$ This duty has been extended to equitable global vaccine distribution to prevent the spread of infectious diseases such as COVID-19. ${ }^{14}$ Vaccine access should not be a question of charity but of states fulfilling their human rights commitments under international law. The high cost of COVID-19 vaccines hinders the realisation of a range of human rights, including the rights to life, equal benefit from scientific progress and health. The CESCR, which recognises vaccines as vital to the realisation of the right to health, has argued that inflexibly applied IP systems and rules that commodify vaccines perpetuate health inequalities and violate human rights. ${ }^{15}$

Ensuring equitable access will require waiving patent law where it undermines state obligations to realise the right to health.

\section{Legal frameworks establish IP and prioritise patents over health}

Global health law encompasses the legal norms, processes and institutions needed to create the conditions for people throughout the world to attain the highest possible level of physical and mental health. ${ }^{16}$ The legal landscape for global health is fragmented, with multiple competing actors and regimes covering areas such as health security, border control, surveillance, trade and IP. ${ }^{17}$ At the intersection of global health and human rights, this fragmentation is further exacerbated by a division of global health law into separate regimes emanating from the International Health Regulations (IHR), on the one hand, and international human rights law, on the other. This has led to calls for global health law and human rights law to be 'harmonized'. ${ }^{18}$

The development and dissemination of COVID-19 vaccines has highlighted how the international legal system pertaining to global health is driving global health inequalities instead of alleviating them. As a result, in part, of neocolonial 'development' models that promote inequitable IP laws, most of the vaccine supply has been manufactured in the Global North and purchased by governments in those countries to be stockpiled for their own populations-a practice sometimes described as 'vaccine hoarding' or 'vaccine nationalism'. ${ }^{20}$ 
Even where countries in the Global South have produced vaccines themselves in significant quantities, they have sometimes been guilty of perpetuating inequity of other Global South countries through vaccine nationalism and vaccine diplomacy, in which vaccines are offered to poorer countries in order to achieve geopolitical objectives. ${ }^{21}{ }^{22} \mathrm{~A}$ decolonised approach to global health enables us to conceptualise this behaviour as a reproduction of a neocolonial system which pits some formerly colonised countries against others. ${ }^{23} 24$ This has meant that some countries in the Global South also benefit from this uneven system, and they too contribute to the exploitation of poorer countries in the Global South. ${ }^{21}$

Although the WHO cocreated the COVAX Facility, a donor-funded mechanism that seeks to pool procurement to enhance access to vaccines for LMICs, the charitable funding scheme is facing a serious shortfall in meeting global needs. The WHO has estimated that most people in LMICs will not be vaccinated until the end of $2023,{ }^{25}$ and even this estimate may be optimistic, given the delays in initial distributions through COVAX. ${ }^{26}$

This prompts the obvious question: How is it that existing legal mechanisms, or at least the prevailing interpretations and understandings of them, have permitted and even enabled this inequity? International IP law embedded in international trade agreements allows pharmaceutical companies time-limited rights to prevent others from making, using or selling their patented invention without permission. Under the 1995 Agreement on Trade-Related Aspects of Intellectual Property Rights (TRIPS), which was included in the Uruguay Round of multilateral trade negotiation, pharmaceutical companies have at least 20 years from filing a patent to profit from their investments in developing, testing and upscaling pharmaceutical products throughout the world. ${ }^{27}$ This protection is given to pharmaceutical companies to incentivise them to engage in greater research and development for new drugs. However, there is evidence that challenges previous assumptions about the linkages between Research and Development spending and innovation for essential medicines. ${ }^{28}$ The current COVID-19 crisis has brought this into sharp focus, with projections that the global public sector had spent at least $€ 93$ billion on the development of COVID-19 vaccines and therapeutics- $€ 85.6$ billion of this on vaccines. ${ }^{29}$

Global IP rights, whether adopted in accordance with TRIPS, or subsequent bilateral and multilateral agreements, are part of a wider legal system which facilitates global neocolonialism. For instance, powerful actors such as the European Union (EU) and the USA have included TRIPS-plus provisions in bilateral and multilateral agreements. These agreements often force countries of the Global South to concede to more stringent patent protections in order to gain trade advantages and also to escape trade sanctions. ${ }^{30}$

In so doing, IP law commodifies medicines that are essential to human survival and well-being, and sacrifices the lives and health of the poor and otherwise marginalised on the altar of corporate profitability. ${ }^{31}$ Common interpretations and understandings of the international IP system are that healthcare goods and services derive their value from their tradability. ${ }^{14}$ ('We use the term "public good" as it is used in global health to mean a good that should be available universally because of its critical importance to health, and not as the term is used in economics to mean a good that is both non-excludable and non-rivalrous.' ${ }^{1432}$ However, many, including critical Global South scholars, have questioned the prioritisation of property rights (including IP rights) over other rights (especially the rights to health, life and equal benefit from scientific progress) in a manner that is inconsistent with international human rights law. ${ }^{31}$

Many low-income countries have long been active in resisting the IP system as an unjust extension of a colonial trade system. At the height of the HIV pandemic, in which millions of people in the Global South were denied lifesaving medicines, civil society treatment access campaigns galvanised states within the World Trade Organization (WTO) into agreeing to the Doha Declaration on TRIPS and Public Health. ${ }^{33}$ This WTO Declaration recognises human rights and allows states to use all of the 'flexibilities' within the TRIPS regime to protect public health, acknowledging the need for access to medicines in a public health emergency. ${ }^{34}$ However, this international consensus on IP has always been strongly contested by pharmaceutical companies and their host governments, predominantly in the Global North.

This remarkably strong resistance to employing TRIPS flexibilities has continued in the current COVID-19 crisis, as the attempts of countries largely from the Global South to try to obtain a TRIPS waiver to increase their supply of vaccines for COVID-19 have been unsuccessful. Although the USA has recently supported a watered-down version of a TRIPS waiver, it remains far from certain whether other states in the Global North will support this prioritisation of health over IP rights, or whether this would be sufficient, as we discuss in the section on flexibilities below.

Rather than allowing for equitable vaccine access as a human right for all people everywhere, states have instead turned to a charitable donation and market purchase scheme through the COVAX initiative. This type of model, which focuses on charity and not rights, is consistent with exactly the kind of understandings of human rights and public health that are in need of decolonisation. While there have been public consensus statements issued by the Human Rights Council, in which states have agreed that all states have the right to access vaccines and the right to use TRIPS flexibilities, this statement reflects a disappointing failure to acknowledge any corresponding state obligations to employ such flexibilities. ${ }^{35}$ This has allowed countries from the Global North, and their few Global South allies, to agree to this statement and support the right to vaccine access rhetorically, and in principle within the Human Rights Council, while 
resisting any calls for a TRIPS waiver within the WTO, and thus consolidating a denial of their obligations to employ TRIPS flexibilities.

\section{The failure of TRIPS flexibilities}

Although countries from the Global South have the option of engaging TRIPS flexibilities in the absence of a general waiver, they often do not do so because the process of using these flexibilities is often stacked against them, reproducing neocolonial dynamics. For instance, TRIPS allows states with limited manufacturing capacity to waive a patent for a limited duration so as to import essential medicines through a compulsory licence. However, in practice, this process is lengthy and complex, as it relies on ensuring that both the importing and exporting countries have enacted local laws that permit them to use TRIPS flexibilities. Further, the importing country needs to negotiate with the pharmaceutical company in order to establish a fair price, which is always tricky, but made significantly more difficult in a crisis. To date, this process has been used only once, when Rwanda obtained access to generic antiretrovirals through an importation agreement with the Canadian company Apotex. However, even in that context, although Rwanda notified the WTO Council of its intention to use the mechanism in July 2007, it took 15 months before it could import its first batch of antiretrovirals. Despite its strong support, the manufacturer Apotex felt that the process was too cumbersome to use again. ${ }^{36}$

This complexity has been heightened during the COVID-19 crisis due to the speed at which vaccines were manufactured, which has created a lack of transparency around the patent process. ${ }^{37}$ Thus, the Bolivian government, which is seeking to use TRIPS flexibilities through compulsory licences, recognises in their application that there is a lack of clarity around the exact extent of product and process patents for any of the existing COVID-19 vaccines due to inadequate information about manufacturing or regulatory processes in different countries. ${ }^{38}$ Additionally, many countries that have manufacturing capacity, such as those in the EU, have not sought to support countries in the Global South that want to use these flexibilities. In sum, cumbersome rules, political and economic pressures and a lack of transparency conspire to enable the Intellectual Property Regime (IPR) system to sustain and deepen global health inequities.

\section{Entrenching inequalities between countries}

The current global distribution of COVID-19 vaccines is largely dictated by power disparities and inequities in financial and other resources, with predominantly highincome countries contracting bilaterally with individual pharmaceutical companies (many in their own countries) for specific vaccines, leaving countries from the Global South facing inequitable vaccine access. Bilateral deals between states and pharmaceutical companies, whether completed by Global North or Global South states, significantly compromise the effectiveness and equity of the COVAX initiative, limited as it already is by the coercive influence, vested interests and participation of pharmaceutical companies and their host nations. The African Union, for example, endorsed the TRIPS waiver to relax WTO rules so that LMICs could create their own COVID-19 vaccines, but this collective effort across African countries faced resistance from Global North countries and pharmaceutical companies.

The IP system appears to have pushed countries in the Global South that may prefer not to be dependent on the charitable model of the COVAX scheme to join highincome countries in engaging directly with manufacturers to purchase COVID-19 vaccines. This has included African countries, despite the African Union's criticism of the inequities resulting from IP law protections. This process has reproduced colonially entrenched power dynamics, in which poorer countries lack the bargaining power to obtain competitive rates and, consequently, typically end up paying far more than the wealthier, developed countries. More broadly, countries in the Global South are pressured into participating in global systems of trade that result in the exploitation of their own populations by unjust global economic systems and IP laws. ${ }^{39}$ The high cost of vaccines for countries from the Global South constitutes a large proportion of their health expenditure, and this comes at the expense of other health priorities.

In many cases, the only way in which Global South countries can purchase vaccines is to move themselves further into debt. Given the detrimental neocolonial implications of debt, with a long history of loan conditionalities through structural adjustment programmes, increasing debt to service health needs contributes to the worsening of inequalities between the Global North and Global South. ${ }^{40}$ These programmes may increase debt and undermine development in ways that limit the realisation of the right to health. ${ }^{41}$ The World Bank has set aside US $\$ 12$ billion and has already disbursed loans of US\$500 million for vaccines in low-income and middleincome nations; ${ }^{42}$ poorer nations, instead of servicing already depleted health systems, are forced to divert additional funds to servicing debt.

\section{Entrenching inequalities within countries}

The high costs of vaccines also propagate inequalities within nations, as desperate countries try to recoup some of the costs by charging their people for vaccine access or using complex arrangements that prioritise some people over others. Egypt, for instance, is charging for the COVID-19 vaccine, which is likely to exclude the poorest people, who have already been severely affected by the crisis. ${ }^{43}$ In reality, it also means that wealthier individuals are prioritised, as they usually find it easier to pay for access. Those able to access vaccines in these countries, very often a small economic and political elite, are often in positions of power precisely along the lines of existing global inequalities and often to the prejudice of groups marginalised on the basis of gender, race and 
other grounds of discrimination prohibited under international human rights law.

Facilitating vaccine access for more affluent members of society reinforces power structures at the expense of marginalised populations. In South Africa, conservative non-governmental organisations aligned closely with the interests of the white minority and elite corporate interests launched a court challenge in order to procure private supplies of vaccines, bypassing the nationwide mechanisms set up by the government to ensure equitable vaccine access. However, having faced opposition from human rights activists and the South African government, this litigation was ultimately withdrawn. (For more information on this litigation see ref $^{4445}$.) Kenya has also prioritised diplomats for COVID-19 vaccination at the expense of health workers, and Indonesia has suggested that the 'more productive' members of society be vaccinated first. ${ }^{46} 47$ In other countries, such as Peru, political elites and their families and friends were secretly vaccinated before the broader populations. (See as examples $\operatorname{ref}^{48}{ }^{49}$.)

An important issue at the boundary of national and international concerns is the potential use of "vaccine passports ${ }^{50}$ Free movement of goods is integral to one of the core objectives of the IHR, and yet many governments are proposing the use of COVID-19 vaccination passports as a mechanism for reopening their economies, which would discriminate against those who have not been vaccinated. The EU introduced vaccine passports in the summer of 2021 for entry into the eurozone and excluded vaccines that were made from the Serum Institute in India which is responsible for the majority of vaccines provided in the Global South. ${ }^{51}$ Vaccination disparities both within and between countries mean that many people in LMICs are unlikely to be vaccinated until 2023; therefore, vaccine passports would only further exacerbate both national and global inequalities and disproportionately restrict the rights of large swathes of the global population from exercising their right to freedom of movement on an equal basis.

\section{TOWARDS A DECOLONISED APPROACH TO HUMAN RIGHTS FOR VACCINE ALLOCATION}

A decolonised approach to human rights demands that providing access to essential therapeutics such as vaccines should be prioritised through domestic, regional and international funding mechanisms to ensure that all states have adequate resources for the realisation of the right to health-including in the present context of COVID-19 vaccines-within a public health crisis brought about by a pandemic. This therefore necessitates a radical rethinking of the ways in which fragmented legal regimes - through international trade law for IP and international human rights law for the right to health-serve to reinforce patent law at the expense of access to vaccines. The process of decolonisation involves centring human rights differently. Human rights are no longer understood as being detached from geopolitics or history but transformed to serve those whose rights are being violated. ${ }^{52}$ We suggest three ways in which decolonisation can 'radically reconceptualise' global health. ${ }^{53}$

\section{Entrenching solidarity: reparations as a response to global inequalities}

Under the ICESCR and IHR, states have a duty to cooperate with other states in progressively realising the right to health, including ensuring provision of minimum levels of health services, facilities and goods on a nondiscriminatory basis. ${ }^{555}$ The CESCR has clarified that, in the context of COVID-19, this duty should include: 'sharing of research, medical equipment and supplies, and best practices in combating the virus; coordinated action to reduce the economic and social impacts of the crisis; and joint endeavours by all States to ensure an effective, equitable economic recovery'. ${ }^{56}$ Additionally, it affirmed that 'the needs of vulnerable and disadvantaged groups as well as fragile countries, including least developed countries, countries in conflict and post-conflict situations, should be at the centre of such international endeavours'. ${ }^{56}$

Many statements from various UN treaty bodies have acknowledged that ensuring universal access to essential medicines is central to the realisation of the right to health, and that IP considerations should never over-ride human rights obligations for universal and equitable access to the COVID-19 vaccine. ${ }^{57-62}$ These statements have been achieved through a global movement of solidarity, encompassing states, civil society organisations and individuals, and reflect a reassessment of human rights values from below. For instance, the Special Rapporteur on the right to health has argued that solidarity needs to be part of a wider effort to redistribute health resources. However, these statements need to go further and call for explicit reparations in global health, which is the only way to redistribute health resources globally. ${ }^{463}$

Increased financing could fund public research and development through either WHO's existing efforts for a complementary research and development treaty, ${ }^{64}$ or through mechanisms such as the proposed Pandemic Financing Facility. The latter proposes to mobilise longterm contributions of approximately US $\$ 5-\mathrm{US} \$ 10$ billion per annum to finance preparedness, but should also focus on funding research and development on pathogens so as to restructure patents as a global public good. ${ }^{65}$ For those states unable to fund their own access to COVID-19 vaccines, there is an international human rights duty on other states to ensure that such states are not harmed through the actions of multilateral institutions that leave them with devastating debt (The Maastricht Principles (see note ${ }^{57}$ ), Principles 3,4 and 9). ${ }^{66}$

In meeting these international obligations immediately to ensure access to COVID-19 vaccines, only a few countries are capable of manufacturing the vaccine at the scale needed. ${ }^{67}$ This inequity in vaccine production capacity requires countries from the Global North to support 
countries in the Global South to increase their production capacity, including through non-exclusive licensing and the WHO's COVID-19 Technology Access Pool. ${ }^{68}$ Sharing technology and building manufacturing capacity will be critical to ensuring that countries can solve problems of access to essential medicines in the long term, setting a precedent that will be necessary in addressing environmental justice, antimicrobial resistance prevention and other global public goods.

Increased funding, as a form of reparations, would help finance a more equitable manufacturing base to ensure that all countries in the Global South are not totally reliant on existing manufacturers. Although we acknowledge that the manufacturing of vaccines is a complex process and that not every country is likely to manufacture medicines including vaccines at the required scale, the WHO has projected that at present, five African countries have some capacity to manufacture vaccines, and efforts to finance manufacturing capacity for countries of the Global South would go a long way towards readdressing the charity model proposed under COVAX by ensuring that African countries can rely on regional compacts for their vaccine access. Coordination and cooperation within the African Union and the Africa Centres for Disease Control and Prevention, which has already begun, could determine the strategically best, and most effective, locations and ways to scale up manufacturing on the continent to improve vaccine access. ${ }^{69} 70$

\section{Human rights obligations beyond the state}

A decolonial approach to human rights acknowledges the historical and present-day role of corporations in the perpetuation of poverty and inequality and must deal head on with the ethical and legal obligations of corporations in global health. Human rights communities have struggled to attribute human rights responsibilities to corporations due to the historical fixation on the state as the locus of human rights obligations. While international human rights law now recognises a direct responsibility on corporations to respect human rights, including the right to health, ${ }^{71}{ }^{72}$ this has been understood largely only as a negative obligation, urging them not to make human rights outcomes worse (see note ${ }^{54}$ ). ${ }^{71} \mathrm{~A}$ decolonial approach must challenge the systems that sustain IP inequalities in preventing access to vaccines. To do so necessitates being clearer about the human rights norms and principles that apply to non-state actors, such as corporations. $^{73}$

States have obligations to regulate corporations such as pharmaceutical companies effectively in order to ensure that they are not violating the right to health (see note $\left.{ }^{56}\right) .{ }^{54}$ Such regulatory measures must be implemented within domestic, regional and international platforms, including through multilateral institutions, such as the WHO and the WTO. In taking this responsibility seriously, states would need to work towards greater coherence, which would avoid weaker human rights obligations within trade-related forums such as the WTO.
Other global health bodies, such as the IHR, as well as any proposed new pandemic treaty, will need to ensure that they are not merely diluting these corporate responsibilities but trying to clarify and strengthen them in line with international human rights law.

Our push for a radical and decolonised understanding of human rights demands that we move away from 'an emergent trade-related, market-friendly paradigm of human rights' to human rights that are grounded in the experiences of people from the Global South. ${ }^{74}$ Thus, a decolonised approach to human rights requires us to expand our understanding of obligations of corporations to avoid measures and practices which: exacerbate supply scarcity or delays in access to COVID-19 vaccines; exacerbate lack of affordability of COVID-19 vaccines; omit principles of equity and non-discrimination from their business decisions; and lack transparency or prevent states from providing information about their interactions in relation to essential medicines such as vaccines. ${ }^{74} 75$ By denying people vaccines, states are subject to worse health outcomes, thus falling short of their negative duties, but we also need to compel corporations to be more proactive in respecting human rights and consider strongly what positive duties they may carry in terms of international human rights law. While this may be anathema to international human rights law at present, it is not without its supporters and effective domestic precedent. (General Comment 24 (see note ${ }^{74}$ ) which refers to a judgement of the South African Constitutional Court in Daniels v Scribante and others, case CCT 50/16, judgement of 11 May 2017, paras 37-39 in which positive duties were imposed on a private owner of land. See also ef $^{76}$.)

\section{Refocusing on human rights as political tools of activism}

Human rights are inherent, and therefore they act as the locus for all forms of emancipation or possibilities that enable people to avoid suffering. Rights are therefore tactics that are employed by people, states and other actors to seek protections for themselves and other actors. Additionally, decolonising human rights also has policy implications, and broader implications for an overall approach to public health and human rights. This is why the UN Special Rapporteur on Health has recently framed her entire mandate through a lens of decoloniality as a mechanism of challenging epistemic failures that challenge the realisation of the right to health. ${ }^{77}$

In our analysis, we have pointed out that although there are broader struggles between the Global North and Global South countries, the neocolonial landscape within which IP rights exist also benefits some countries of the Global South, such as India and China, who are now engaged in vaccine diplomacy. At the national level, we also see inequalities that serve the elite over marginalised groups, such as refugees or migrants. A decolonised approach to human rights must be rooted in the experiences of those whose rights are violated.

Countries in the Global South should ensure that they treat the COVID-19 vaccine as an essential medicine, 
which is part of states' core obligations under the right to health, and must therefore be realised immediately, universally and without discrimination. We argue that COVID-19 vaccines should be available free at the point of access and that all inhabitants of every country are given access to such vaccines without discrimination, and prioritised in accordance with health vulnerability rather than financial resources. Allowing for, and contributing to, the perpetuation of dual tracks that entrench inequalities violates these binding human rights obligations.

\section{CONCLUSION}

As scholars and activists from the Global North and Global South who have been advocating for the full realisation of human rights throughout the pandemic, especially around access to essential medicines such as COVID-19 vaccines, we intend this article to contribute to a broader conversation on the need for the decolonisation of human rights in global health and to illustrate that human rights should be more emancipatory. Human rights require equality in access to vaccines, rather than the limited and ineffective charity currently made available in a glacial manner through initiatives like COVAX.

For Global South countries, the decolonisation of human rights in health is a potentially radical and transformative agenda, which would contribute to ensuring that vaccines are provided equitably, transparently, freely and universally at the point of access. It would contribute towards breaking the spell of regressive and inflexible application of patents acting as the over-riding consideration in all matters of vaccine production and distribution. The COVID-19 vaccination process is one of the greatest global health challenges of our time, and we must ensure that we use this moment to better conceptualise the ways in which we collectively think about the right to health of all people, everywhere.

Twitter Sharifah Sekalala @sharifasekalala, Lisa Forman @lforman and Benjamin Mason Meier@BenjaminMMeier

Contributors SS (lead author) conceived the idea, wrote the first draft and drafted the final version of the manuscript. The rest of the authors contributed equally to further conceptualisation of the ideas and editing the draft.

Funding This project was funded by an IRSF grant from the University of Warwick. Competing interests None declared.

Patient consent for publication Not required.

Provenance and peer review Not commissioned; externally peer reviewed.

Data availability statement There are no data in this work.

Open access This is an open access article distributed in accordance with the Creative Commons Attribution Non Commercial (CC BY-NC 4.0) license, which permits others to distribute, remix, adapt, build upon this work non-commercially, and license their derivative works on different terms, provided the original work is properly cited, appropriate credit is given, any changes made indicated, and the use is non-commercial. See: http://creativecommons.org/licenses/by-nc/4.0/.

\section{ORCID iDs}

Sharifah Sekalala http://orcid.org/0000-0002-5434-5245

Lisa Forman http://orcid.org/0000-0002-4200-9359

\section{REFERENCES}

1 Smith T. Decolonizing methodologies research and Indigenous peoples. 3rd edn. Zed Books, 1999.

2 Forman L. Global health governance from below: access to AIDS medicines, International human rights law and social movements. In: Cooper AW, Kirton J, Schrecker T, eds. Innovation in global health governance: critical cases. Ashgate publishers, 2009: 193-207.

3 Affun-Adegbulu C, Adegbulu O. Decolonising global (public) health: from Western universalism to global pluriversalities. BMJ Glob Health 2020;5:e002947.

4 Shamasunder S, Holmes SM, Goronga T, et al. COVID-19 reveals weak health systems by design: why we must re-make global health in this historic moment. Glob Public Health 2020;15:1083-9.

5 Balakrishnan R. International law from below: development, social movements and third World resistance. Cambridge University Press, 2003.

6 Baxi U. The future of human rights. Oxford University Press, 2002.

7 De Sousa Santos B. Toward a new legal common sense: law, globalization and emancipation. In: Butterworths lexis nexis. 2nd edn, 2002.

8 Büyüm AM, Kenney $C$, Koris $A$, et al. Decolonising global health: if not now, when? BMJ Glob Health 2020;5:e003394.

9 Nkrumah K. Neocolonialism: the last stage of imperialism. Int/ Pub 1965:861-78.

10 Forman L. From TRIPS-Plus to Rights-Plus? Exploring right to health impact assessment of trade-related intellectual property rights through the Thai experience. Asian Journal of WTO and International Health Law and Policy 2012;7:347-75.

11 United Nations Human Rights Office of the High Commissioner (OHCHR). International covenant on economic, social and cultural rights, 1966. Available: https://www.ohchr.org/documents/ professionalinterest/cescr.pdf

12 Perehudoff SK, Alexandrov NV, Hogerzeil HV. Legislating for universal access to medicines: a rights-based cross-national comparison of UHC laws in 16 countries. Health Policy Plan 2019;34:iii48-57.

13 United Nations Committee on Economic, Social and Cultural Rights (CESCR). Statement on universal affordable vaccination against coronavirus disease (COVID-19), international cooperation and intellectual property. Available: https://undocs.org/E/C.12/2021/1 [Accessed 23 Apr 2021].

14 Gostin LO, Karim SA, Mason Meier B. Facilitating access to a COVID-19 vaccine through global health law. J Law Med Ethics 2020;48:622-6.

15 CESCR. General Comment No. 25 on science and economic, social and cultural rights, 2020. Available: https://undocs.org/E/C.12/GC/ 25

16 Gostin L, Taylor A. Global health law: a definition and grand challenges. Public Health Ethics 2008;1:53-63.

17 Gostin LO, Monahan JT, Kaldor J, et al. The legal determinants of health: harnessing the power of law for global health and sustainable development. Lancet 2019;393:1857-910.

18 Roojin H, Meier BM, Hodgson TF. Harmonizing global health law and human rights law to develop Rights-Based approaches to global health emergencies. OpinioJuris, 2021. Available: http://opiniojuris. org/2021/02/24/harmonizing-global-health-law-and-humanrights-law-to-develop-rights-based-approaches-to-global-healthemergencies/ [Accessed Apr 2021].

19 BBC News. Covid vaccine: WHO warns of 'catastrophic moral failure'. Available: https://www.bbc.com/news/world-55709428 [Accessed Apr 2021].

20 Williams CR, Kestenbaum JG, Meier BM. Populist nationalism threatens health and human rights in the COVID-19 response. Am J Public Health 2020;110:1766-8.

21 Prabhala A, Menghaney L. The world's poorest countries are at India's mercy for vaccines. It's unsustainable, 2021. The Guardian. Available: https://www.theguardian.com/commentisfree/2021/apr/ 02/india-in-charge-of-developing-world-covid-vaccine-supplyunsustainable [Accessed 2 Apr 2021]

22 Hotez PJ. "Vaccine diplomacy": historical perspectives and future directions. PLoS Negl Trop Dis 2014;8:e2808.

23 Tuck E, Yang KW. Decolonisation is not a metaphor. Decolonization: Indigeneity, Education \& Society 2012;1:1-40.

24 Fujikane C. Asian American critique and Moana Nui 2011: securing a future beyond empires, militarized capitalism and APEC. Inter-Asia Cultural Studies 2012;13:189-210.

25 UN News. WHO chief warns against 'catastrophic moral failure' in COVID-19 vaccine access. Available: https://news.un.org/en/story/ 2021/01/1082362 [Accessed Apr 2021].

26 World Health Organization. COVAX updates participants on delivery delays for vaccines from Serum Institute of India (SII) and 
AstraZeneca, 2021. Available: https://www.who.int/news/item/ 25-03-2021-covax-updates-participants-on-delivery-delays-forvaccines-from-serum-institute-of-india-(sii)-and-astrazeneca

27 WHO, World Intellectual Property Organization (WIPO), World Trade Organization (WTO). Promoting access to medical technologies and innovation. Available: https://www.who.int/publications/i/item/ 9789240008267 [Accessed Apr 2021].

28 Trouiller P, Olliaro P, Torreele E, et al. Drug development for neglected diseases: a deficient market and a public-health policy failure. The Lancet 2002;359:2188-94.

29 Hoecklin M. $€ 93$ billion spent by public sector on COVID vaccines and therapeutics in 11 months, research finds. Health Policy Watch. Available: https://healthpolicy-watch.news/81038-2/ [Accessed May 2021].

30 Forman L. Trading health for profit: bilateral and regional free trade agreements affecting domestic property rules on pharmaceuticals. In: Cohen JC, Schuklenk U, Illingsworth P, eds. The power of pills: social, ethical and legal issues in drug development, marketing, and pricing. Pluto Press, 2006.

31 Vanni A. On intellectual property rights, access to medicines and vaccine imperialism. Third World approaches to international law review. Available: https://twailr.com/on-intellectual-property-rightsaccess-to-medicines-and-vaccine-imperialism/ [Accessed Apr 2021].

32 WHO WHO SAGE values framework for the allocation and prioritization of COVID-19 vaccination, 2020. Available: https:// apps.who.int/iris/bitstream/handle/10665/334299/WHO-2019nCoVSAGE_Framework-Allocation_and_prioritization-2020.1-eng. pdf [Accessed Apr 2021].

33 Sekalala S. Soft law and global health problems: lessons from responses to HIVIAIDS, malaria and tuberculosis. Cambridge University Press, 2017.

34 UN Human Rights Council. Report of the special Rapporteur on the right of everyone to the enjoyment of the highest attainable standard of physical and mental health, Anand Grover, 2009. Available: https://www2.ohchr.org/english/bodies/hrcouncil/docs/11session/A. HRC.11.12_en.pdf [Accessed May 2021].

35 Hodgson T, De Falco R. Human rights and universal access to COVID-19 vaccines: does the human rights Council resolution go far enough? OpinioJuris, 2021. Available: http://opiniojuris.org/2021/03/ 23/human-rights-and-universal-access-to-covid-19-vaccines-doesthe-human-rights-council-resolution-go-far-enough/ [Accessed Apr 2021].

36 Sekalala SR. Third World access to essential medicines and the WTO General Council decision 2003. King's Law Journal 2010;21:172-92.

37 Rhodes N, Wright T, Rusu V. For whose benefit? Transparency in the development and procurement of COVID-19 vaccines, 2021. Transparency International. Available: http://ti-health.org/ wp-content/uploads/2021/05/For-Whose-Benefit-TransparencyInternational.pdf [Accessed May 2021].

38 Thambisetty S, McMahon A, McDonagh L. The trips intellectual property Waiver proposal: creating the right incentives in patent law and politics to end the COVID-19 pandemic. LSE legal studies working paper (2021, forthcoming). Available: https://ssrn.com/ abstract $=3851737$ [Accessed May 2021]

39 Sachs JD, Abdool Karim S, Aknin L, et al. Priorities for the COVID-19 pandemic at the start of 2021: statement of the Lancet COVID-19 Commission. The Lancet 2021;397:947-50.

40 Nkrumah K. Neocolonialism: the last stage of imperialism 1965: 861-78.

41 Meier BM, Fox AM. Development as health: employing the collective right to development to achieve the goals of the individual right to health. Human Rights Quarterly 2008;30:259-355

42 World Bank. World bank supports first COVID-19 vaccine Rollout in Lebanon. Available: https://www.worldbank.org/en/news/pressrelease/2021/01/21/world-bank-supports-first-covid-19-vaccinerollout-in-lebanon [Accessed Apr 2021].

43 Human Rights Watch. Egypt: provide equitable COVID-19 vaccine access. Available: https://www.hrw.org/news/2021/03/09/egyptprovide-equitable-covid-19-vaccine-access [Accessed Apr 2021].

44 Business Tech. Court challenge aims to stop 'nationalisation' of COVID-19 vaccines in South Africa, 2021. Available: https:// businesstech.co.za/news/trending/459724/court-challenge-aimsto-stop-nationalisation-of-covid-19-vaccines-in-south-africa/ [Accessed Apr 2021].

45 HJI statement on Afriforum \& Solidarity's withdrawal of its vaccine procurement urgent application, 2021. Available: https://healthju sticeinitiative.org.za/2021/03/29/afriforum-solidarity-case-amicus/ [Accessed April 2021].
46 Lewis D, Fick M. Kenyan COVID vaccine offer to diplomats draws local doctors' ire. Reuters, 2021. Available: https://www.reuters.com/ article/us-health-coronavirus-kenya-idUSKBN2BCOLH [Accessed Apr 2021].

47 Lane M. Commentary: Indonesia's vaccination policies seem to favour the young and rich. CNA. Available: https://www. channelnewsasia.com/news/commentary/covid-19-indonesiavaccine-program-worker-mandiri-jokowi-sinovac-14341636 [Accessed Apr 2021].

48 McDonnell PJ, León A. 'Vaccine-gate' roils Peru: Politicians, families andfriends secretly got COVID shots, 2021. Los Angeles Times. Available: https://www.latimes.com/world-nation/story/2021-02-18/ peru-vaccine-gate-politicians-diplomatsreceived-chinese-vaccine [Accessed Apr 2021].

49 Taj M, Kurmanaev A, Andreoni M. V.I.P. Immunization' for the Powerful and Their Cronies Rattles South America, 2021. The New York Times. Available: https://www.nytimes.com/2021/02/25/world/ americas/covid-southamerica-vaccine-corruption.html [Accessed May 2021].

50 Osama T, Razai MS, Majeed A. Covid-19 vaccine passports: access, equity, and ethics. BMJ 2021;373:n861.

51 Palmer S. EU outlines proposed COVID 'vaccine passport' that could boost travel this summer. euronews.travel, 2021. Available: https://www.euronews.com/travel/2021/03/17/eu-plans-to-boostsummer-travel-with-its-proposal-for-a-digital-vaccine-passport [Accessed Apr 2021].

52 Chakrabarty D. Provincializing Europe: Postcolonial thought and historical difference. Princeton University Press, 2007.

53 Mignolo WD. The many faces of Cosmo-polis: border thinking and critical cosmopolitanism. Public Culture 2000;12:721-48.

54 International Commission of Jurists. Living like people who die slowly: the need for right to health compliant COVID responses. 2020: 19, 15-17. https://www.icj.org/wp-content/uploads/2020/09/ Universal-Global-Health-COVID-19-Publications-Reports-ThematicReports-2020-ENG.pdf

55 The ETO Consortium. Maastricht principles on Extraterritorial obligations of states in the area of economic, social and cultural rights (the Maastricht principles), 2011. Available: https://www. etoconsortium.org/nc/en/main-navigation/library/maastrichtprinciples/?tx_drblob_pi1\%5BdownloadUid\%5D=23 [Accessed Apr 2021].

56 CESCR. Statement on the coronavirus disease (COVID-19) pandemic and economic, social and cultural rights by the Committee on economic, social and cultural rights. E/C.12/2020/1, 2020. Available: https://undocs.org/E/C.12/2020/1 [Accessed May 2021].

57 UN Human Rights Council. Measures taken to implement human rights Council resolution $9 / 8$ and obstacles to its implementation, including recommendations for further improving the effectiveness of, harmonizing and reforming the Treaty body system report of the Secretary-General. A/HRC/46/25, 2020. Available: https:// documents-dds-ny.un.org/doc/UNDOC/GEN/G20/349/38/PDF/ G2034938.pdf?OpenElement [Accessed May 2021].

58 OHCHR. COVID-19: UN experts urge WTO cooperation on vaccines to protect global public health, 2021. Available: https://www.ohchr. org/EN/NewsEvents/Pages/DisplayNews.aspx?NewsID=26817\& LangID=E [Accessed May 2021].

59 OHCHR. Statement by UN human rights experts universal access to vaccines is essential for prevention and containment of COVID-19 around the world, 2020. Available: https://www.ohchr.org/EN/ NewsEvents/Pages/DisplayNews.aspx?NewsID=26484\&LangID=E [Accessed May 2021]

60 CESCR. Statement on universal and equitable access to vaccines for the coronavirus disease (COVID-19), 2020. Available: https:// digitallibrary.un.org/record/3897801? In=en [Accessed May 2021]

61 CESCR. Statement on universal affordable vaccination for COVID-19, international cooperation and intellectual property. E/C.12/2021/1, 2021. Available: https://tbinternet.ohchr.org/_layouts/ 15/treatybodyexternal/Download.aspx?symbolno=E/C.12/2021/1\& Lang=en [Accessed May 2021].

62 United Nations General Assembly. The interim report of the special Rapporteur on the right of everyone to the enjoyment of the highest attainable standard of physical and mental health. A/67/302. Available: https://documents-dds-ny.un.org/doc/UNDOC/GEN/N12/ 461/01/PDF/N1246101.pdf?OpenElement [Accessed May 2021].

63 Richardson ET. On the coloniality of global public health. Medicine Anthropology Theory 2019;6:101-18.

64 United Nations. Report of the United Nations Secretary-General's High-Level Panel on Access to Medicines: Promoting Innovation and Access to Health Technologies, 2016. Available: http://www. unsgaccessmeds.org/final-report/ [Accessed May 2021]. 
65 The independent panel for pandemic preparedness and response. COVID-19: make it the last pandemic, 2021. Available: https:// theindependentpanel.org/mainreport/ [Accessed May 2021].

$66 \mathrm{OHCHR}$. CESCR General Comment No. 14: The Right to the Highest Attainable Standard of Health (Art. 12). Paras 43(d) and 44(b)-(c). Available: https://www.refworld.org/pdfid/4538838d0.pdf [Accessed May 2021].

67 Lurie N, Saville M, Hatchett R, et al. Developing Covid-19 vaccines at pandemic speed. N Engl J Med 2020;382:1969-73.

68 WHO. COVID-19 technology access pool. Available: https://www. who.int/emergencies/diseases/novel-coronavirus-2019/globalresearch-on-novel-coronavirus-2019-ncov/covid-19-technologyaccess-pool [Accessed May 2021].

69 African Union. Virtual Conference: Expanding Africa's Vaccine Manufacturing, 2021. Available: https://africacdc.org/event/virtualconference-expanding-africas-vaccine-manufacturing/ [Accessed May 2021].

70 African Union. African Union and Africa CDC launches partnerships for African vaccine manufacturing (PAVM), framework to achieve it and signs 2 MoUs, 2021. Available: https://africacdc.org/news-item/ african-union-and-africa-cdc-launches-partnerships-for-africanvaccine-manufacturing-pavm-framework-to-achieve-it-and-signs-2mous/ [Accessed May 2021].

$71 \mathrm{OHCHR}$. Guiding principles on business and human rights. principles 11-15. Available: https://www.ohchr.org/documents/publications/guid ingprinciplesbusinesshr_en.pdf [Accessed May 2021]
72 CESCR. General Comment No. 24 (2017) on state obligations under the International covenant on economic, social and cultural rights in the context of business activities (General Comment 24). Para 5. Available: https://www.refworld.org/docid/5beaecba4.html [Accessed May 2021]

73 Gruskin S, Raad Z. Are drug companies living up to their human rights responsibilities? moving toward assessment. PLoS Med 2010;7:e1000310.

74 Baxi U. Market Fundamentalisms: business ethics at the Altar of human rights. Human Rights Law Review 2005;5:1-26.

75 Human Rights Watch. Universal and Equitable Access to Covid-19 Vaccines, Testing, Treatments: Companies' Human Rights Responsibilities Questions and Answers, 2021. Available: https:// www.hrw.org/news/2021/02/11/universal-and-equitable-accesscovid-19-vaccines-testing-treatments-companies-human [Accessed May 2021].

76 Bilchitz D. The Necessity for a Business and Human Rights Treaty. Business and Human Rights Journal 2016;1:203-27.

77 Mofokeng T. Report of the special Rapporteur on the right of everyone to the enjoyment of the highest attainable standard of physical and mental health, Tlaleng Mofokeng. UN human rights Council, 47th session, A/HRC/47/28, 2021. Available: https:// undocs.org/A/HRC/47/28 [Accessed Jun 2021]. 